\title{
Manuscript Codices in the Library Collection of the Cistercian Abbey in Szczyrzyc
}

\begin{abstract}
The collection of manuscripts at the Cistercian library in Szczyrzyc amounts to 100 volumes, including four medieval codices dated between 1460-1494; 12 manuscript books dated to the $17^{\text {th }}$ century; 57 dated to the $18^{\text {th }}$ century, and 27 manuscripts dated to the $19^{\text {th }}$ century. Most of them are textbooks, copies of theological, philosophical and legal treatises, works on rhetoric, liturgy, world history, mathematics and herbal medicine, as well as books of homilies for special occasions and feasts. The collection of manuscripts at the monastery in Szczyrzyc is mostly a functional one - it was used by the monks to study and broaden their philosophical, theological, legal and liturgical knowledge. Several codices contain the texts of homilies delivered at various churches on feast days and solemnities, written down by the monks of Szczyrzyc. The surviving codices are bound in simple covers made of damaged folios taken out from liturgical codices, including antiphonaries and graduals. Considering the small number of surviving books, it is difficult to discuss the interests or influences of particular authors and their works on the intellectual level of the religious community of Szczyrzyc.
\end{abstract}

\section{Keywords}

Monastery; Cistercians; library; Szczyrzyc; codices.

The collection of manuscripts at the Cistercian library in Szczyrzyc amounts to 100 volumes ${ }^{1}$. It includes four medieval codices dated between 1460-1494; 12 manuscript books ( $17^{\text {th }}$ century) dated between 1631 and 1693,57 manuscript books ( $18^{\text {th }}$ century) dated between $1703-1782$, and 27 manuscripts of confirmed

1 J. M. Marszalska, Biblioteka opactwa cystersów w Szczyrzycu do końca XIX stulecia. Dziedzictwo wieków, Tarnów 2007, cf. Annex III.: Katalog ksiag rękopiśmiennych Biblioteki Opactwa Cystersów w Szczyrzycu, item 1-100, p. 312-348. 
$19^{\text {th }}$ century dating ${ }^{2}$. A great majority of these volumes are textbooks - handwritten copies of theological, philosophical and legal treatises - required by the monks of Szczyrzyc in the course of their studies in Mogiła or Oliwa. The collection also includes several manuscripts (textbooks) on rhetoric, works on liturgy, world history, mathematics and herbal medicine, as well as books of homilies for special occasions and feasts.

Only four medieval manuscript codices have survived to modern day $^{3}$, date back to the second half of the $15^{\text {th }}$ century. The oldest medieval codex, Thesaurus concionum by Peter Paludanus with a postilla by Wilhelm of Paris, dates back to about 1460. It was once in the possession of Mikołaj of Jadowniki, as can be seen in the provenience note which says he purchased the work by Paludanus for 3 florins: "Nicolaus de Jadowniky est emptus liber pro tribus florenis"4. Below this note, there is a date written in a different hand: " 1460 ". The code was probably purchased for the monastery - quite possibly from Mikołaj of Jadowniki - by Mikołaj IV (1448-1467), the Abbot of Szczyrzyc whose rule dates to that period. The manuscript still has its original binding: brown skin stretched over a board, with just barely visible blind-tooled print and marks of ornamental centre and corner pieces. Who was the original owner of the manuscript - Mikołaj of Jadowniki, referred to as the "bibliophile peasant"? We know he lived and worked in the $15^{\text {th }}$ century, in the piedmont areas of Lesser Poland. While serving as an assistant curate in Szczepanów, he made a handwritten copy of Pope Gregory the Great's Homilies in 1459 - "drinking water and eating berries", as he wrote himself. A year later (1460), now already a priest working in the village of Zbyszyce in Sądeckie province, he made copies of several treatises by Isidore of Seville ${ }^{5}$.

The second medieval codex is Charta Charitatis, containing, among other things, papal orders and decrees concerning the Cistercian Order. It was purchased for the monastery in Szczyrzyc by Abbot Jacob: “[...] Explicit liber diffinitionum nec non privilegiorum et statuorum papalium comparatus per

2 Ibid.

3 It is probable that the collection of manuscripts used to be much bigger, but based on the surviving specimens it is not possible to determine how numerous it may once have been.

4 J. M. Marszalska, Biblioteka opactwa cystersów w Szczyrzycu do końca XIX stulecia..., Annex III, item 1, p. 312.

E. Potkowski, Książka rękopiśmienna w kulturze Polski, Warszawa 1984, p. 87; Cf. L. Zalewski, Chłop bibliofil w XV wieku, Lublin 1946, p. 10-12. 
Venerabilem virum Jacobum Abbatem, primo anno promotionis sive Anno Dni $1464 "$.

The above ownership note is rather confusing, as according to information found in the reference sources retained at the monastery, e.g. Servitus Sancta coram Deo..., the abbot of the monastery in Szczyrzyc at that time was Mikołaj IV (1448-1467), and Jacob had been the abbot in the years 1382-13977. This may be due to a dating error.

The codex was made with much care and attention to detail. The text itself is rubricated and ornamented with red-ink initials. Its one-hand type duct suggests it was copied by a single scribe. The abundant marginal glosses in more than a dozen hands $\left(16^{\text {th }} / 17^{\text {th }}\right.$ century) show the codex was much studied. As a matter of interest, a list of prioresses and abbots of Cistercian convents and monasteries in Lesser and Greater Poland for the years 1500-1627 was added at the end of the codex several ages later by Zygmunt Strychowski, a chronicler and prior of the monastery in Szczyrzyc ${ }^{8}$. The codex still has its original binding dated to the turn of the $15^{\text {th }}$ and $16^{\text {th }}$ centuries, consisting of a board and smooth, brown skin with visible marks of eight round corner pieces and two centre pieces.

The third preserved manuscript codex is Catholicon by John Balbi of Genoa, a popular medieval publication. On the lower margin of the first page appears the date: " 1470 ". The codex was carefully written by one scribe in black and red ink. The text is rubricated, with initials in red and green ink. There is no mention of when or by whom the codex was purchased for the monastery in Szczyrzyc. The only confirmed fact is that it was held at the monastery during the rule of Abbot Stanisław I (ca. 1467 - ca. 1481), i.e. in the second half of the $15^{\text {th }}$ century. The original binding is well preserved - brown skin stretched

6 J. M. Marszalska, Biblioteka opactwa cystersów w Szczyrzycu do końca XIX stulecia... Annex III, item 2, p. 312.

7 Servitus Sancta coram Deo, et omnibus Sanctis ... secundum Regulam P.P. Benedicti Constitutiones Ordinis Cisterciensis ... compilata ... descriptus 1751, p. 4, no ref.; J. M. Marszalska, W. Graczyk, Opaci i przeorzy klasztoru oo. Cystersów w Szczyrzycu od XIII-XX wieku, Tyniec 2006, p. 42,55 .

8 Zygmunt Strychowski was an ordained monk of the Cistercian order in Kronów, a monk at the monastery in Szczyrzyc; under the rule of Abbot Stanisław Drohojewski (1607-1632) he held the office of prior. He was the author of the cartulary Origo II. Cf. J. M. Marszalska, Najważniejsze źródła rękopiśmienne do dziejów klasztoru oo. Cystersów w Szczyrzycu, "Nasza Przeszłość" 104 (2005), p. 37-70. 


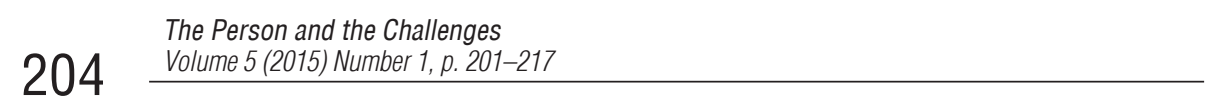

over lime wood board, with blind-tooled geometrical lines and lilium regale shapes. Two wrought catch plates are still attached to both boards.

The fourth preserved $15^{\text {th }}$ century codex is not a coherent whole in terms of subjects covered. It is a collection of various texts, copied by a single scribe, as can be seen from the uniform type duct. The texts have separate pagination within the adligat. The whole was written on paper in Latin, with only a small passage in Polish. At the end of the text, below the manuscript catalogued under number 4.3. De conversatione optima diversorum Sanctorum [...] Incipiunt Septem capitula, quae misit Abbas Moyses Abbati [...], there is a dating: "Sub Anno Dni 1494". Thus, the entire adligat is conventionally dated to the year 14949. It includes the following titles:

1. Incipit Liber Exhortationum ex Vitas Patrum desumptus [...] (fols. 1-18);

2. Incipit Primum Capitulum. Admonitio de Laude Charitatis. (fols. 19-31);

3. Incipiunt Sermones S. Augustini ad heremitas et nonulli ad Sacerdotes [...] de institutiorum regularum vitae [...] (fols. 32-63);

4. De Conversatione optima diversorum Sanctorum [...]Incipiunt Septem capitula, quae misit Abbas Moyses Abbati [...] (fols. 64-84);

5. Polska Msza to iesth Wykład Przednieyszych tajemnic Mszey Świętey, teraz znowu z niemieckie na polskie przełożona [...]Pierwsza część co tajemnice Mszey Świętey znacza [...] (Polish Mass, or an Explanation of the Principal Mysterie of the Holy Eucharist, translated from German into Polish [...] Part One: On the Meaning of the Eucharistic Mysteries [...]) (fols. 85-94);

6. Oratio revocatoria S. Cypriani [...] (fols. 95-97);

7. Ex Pontificali ad Sacerdotes. Summi Pontificis admonitio ad Sacerdotes [...] (fols. 98-100); Incipit tractatus dubiorum ac difficultatum circa officium Missae, et ea que ad debitam eiusdem celebrationem exiquntur frequentis occurentium iuxta Sacror canonum constitutiones: probatorumque Doctorum firmores atque tutiores sententias resolutionibus (fols. 101-122). Its so-called "wastepaper" binding was added much later. It was made of cardboard enveloped in a piece of a manuscript sheet with well-preserved musical notation. It is a specimen of reclaimed binding often encountered in monastic book collections.

9 For example, under the text catalogued as No. 4.5 "Oratio revocatoria P. Cypriani [...]" the inscription says: "Sigillum Mariae Divinae, scriptum est [...] 13 julij 1583”; Cf. J. M. Marszalska, Biblioteka opactwa cystersów w Szczyrzycu do końca XIX stulecia... Annex III, item 4, p. 313. 
The surviving medieval manuscript codices have later ownership notes of the abbey in Szczyrzyc. They were added in the first half of the $18^{\text {th }}$ century, when a complete inventory of the monastery's property was taken, including the library and the archives ${ }^{10}$. In the first three codices, the note says: "Ex libris Fratrum Monasterij Ciricensis", and the note in the fourth one says: "Fratrum Monasterii S[acri] O[rdinis] C[isterciensis]", followed by the date "1729".

As has been mentioned above, the collection of manuscripts includes 12 codices dating back to the $17^{\text {th }}$ century: the years $1631-1693$. Some of them lack the full date of origin, first or last name of the scribe. One of the codices whose dating could not be precisely established is an interesting manuscript entitled Rubricae in celebratione Sanctae Missae calendarium. It was written on parchment in black, red and blue ink.

The codex consists of 113 bound folios. Many have small, elaborate, colourful initials with elements of floral ornamentation. On sheets $13 \mathrm{v}$. and 14 , there are drawings illustrating the phases of the moon. On the following pages, the codex features a calendar of Catholic church holidays with references to the day, month and year. The entire text is rubricated. The codex was probably produced in the monastery in Szczyrzyc. The anonymous monk (scribe) who wrote it was very talented, as can be seen in the artistry of the drawings illustrating the phases of the moon. The ownership note found in the codex was added in the $18^{\text {th }}$ century. It is in the form of the well-known formula: "Ex libris fratrum Monasterij Ciricensis". There are no marginal glosses in the manuscript. The code is bound in thin cardboard covered with a fragment of a parchment manuscript folio from another book. This type of wastepaper binding, frequently encountered in the codices held at Szczyrzyc, suggests it could have been bound by an anonymous monk from the monastery.

The remaining $17^{\text {th }}$ century codices have full dating, usually placed in the title of the work. They are books on philosophy, moral theology, liturgics, and books of homilies. Some of them are copies of original works, or their fragments, by most outstanding thinkers, including Aristotle, Saint Augustine,

${ }^{10}$ Inventarium Cijrzickiego Kościoła ... conscriptus R.P. Antonius Stawski...1728-1740, p. 40, no ref.; J. M. Marszalska, Mikołaj Romiszowski profes paradyski, późniejszy opat szczyrzycki wświetle wybranych dokumentów opactwa oo. Cystersów w Szczyrzycu, in: Opactwo cysterskie w Paradyżu. Jego rola w dziejach i kulturze pogranicza, Zielona Góra 2004, p. 73-84; J. M. Marszalska, Opaci komendataryjni wobec książki. Przyczynek do dziejów opactwa Cystersów w Szczyrzycu, w: Klasztor w państwie średniowiecznym i nowożytnym, ed. M. Derwich, A. Pobóg- Lenartowicz, WrocławOpole-Warszawa 2005, p. 351-363. 
Albertus Magnus, or Thomas Aquinas. The oldest of the codices dated to the $17^{\text {th }}$ century is In libros Aristotelis de generatione et corruptione. Oficiae Universae Philosophiae. A.D. 1631, and consists of 600 folios. It was written on handmade paper by one person - Marcin Pawlikowski, abbot of the monastery in Szczyrzyc"11, as can be read in his handwritten note: "Martinus Pawlikowski, Abbas Ciricensis, Ord. Cisterciensis". This is followed by a note saying: "Ex libris Conventus Ciricensis" ( $1^{\text {st }}$ half of the $18^{\text {th }}$ century). The codex has no binding. The books on philosophy include another codex, In disputationes philosophicas. Cursum totius Logicae. Rhetorica ad C. Herennium. Libros octo Phisicorum. Anno Dni 1638. It consists of 524 folios and was copied by an anonymous scribe ${ }^{12}$. There are no earlier provenience notes in the book, and there is no binding. Another book on philosophy is In philosophiam Magni Alberti. [Dialectica]. Scriptum Iacobi Górsci in Claro Tumbano Collegio. Anno Dni 1646”, copied in 1646 by Jakub Górski at the Cistercian monastery in Mogiła. It includes 528 folios written in a small, careless hand, often difficult to read; the codex has no binding ${ }^{13}$.

The collection of $17^{\text {th }}$ century manuscripts on spiritual theology includes a work entitled Abecedarium Vitae Spiritualis complectens multa breviter et Clare de natura causis gradibus, mediis, impedimentis, instrumentis, practicis, religiosae, perfectionis omnibus Vitae Asceticae Tyronibus immo et Veteranis scitu per quam necessarium [...] per Stanislaus Lorkowicz. Its most probable dating is 1622 . The codex consists of 355 paperfolios, written in a very careful hand suggesting single authorship. Both the title and the provenience note refer to Stanisław Lorkowicz, a monk at the Jesuit St. Barbara monastery in Krakow: "est per Stanislaus Lorkowic [...] in Conventii Novitiatus S. Barbara [...]"14.

An interesting example of books on eschatology is another codex: Dysertacya konających gdzie podaje się sposób naprzód, jako się wszyscy na śmierć zawczasu maja gotować, po tym jako Kapłani i insi przytomni, maja ratować

${ }^{11}$ J. M. Marszalska, Biblioteka opactwa cystersów w Szczyrzycu do końca XIX stulecia... Annex III, item 6, p. 315; J. M. Marszalska, W. Graczyk, Opaci i przeorzy klasztoru oo. Cystersów w Szczyrzycu, p. 127-129.

12 J.M. Marszalska, Biblioteka opactwa cystersów w Szczyrzycu do końca XIX stulecia... Annex III, item 7, p. 315-316.

13 J. M. Marszalska, Biblioteka opactwa cystersów w Szczyrzycu do końca XIX stulecia..., item 8, p. 316.

${ }_{14}$ J. M. Marszalska, Biblioteka opactwa cystersów w Szczyrzycu do końca XIX stulecia..., item 9, p. 316. 
konajacych. (A Dissertation for the dying, with instructions on how to prepare oneself for death, and on how Priests and others present should come to their rescue.) Hic Liber Propria manu scripsit est Fratris Damasi a BV Maria de Monte Carmeli pro tunc [...] Anno Domini 1687. Conventus Posnaniensi CD [...] est sub titulo S. Josephi applicetur, authored by a Carmelite, Damazy of Our Lady of Mount Carmel, who was at that time staying at the monastery in Poznań. The manuscript consists of 322 folios. It was copied in Polish, in a single hand, often illegible. Its wastepaper binding was made of soft cardboard, with the spine reinforced with brown half-binding ${ }^{15}$.

$17^{\text {th }}$ century manuscript codices covered topics in philosophy, theology and preaching. Examples include: Kazania różne, różnych czasów, na różnych miewane mieyscach ... przez X. Andrzeya Benedykta Kmite, Proffessa natenczas, Podprzeorzego Czijrzickiego Zakonu Świętego Cistercienskiego. [...]. Kazanie na Niedziele, Anno Dni 1691 w Kościele Czijrzickim odprawione (Various homilies, on various occasions, delivered at various places... by Father Andrzey Benedykt Kmita, then an ordained monk, subprior at the Holy Cistercian Monastery in Szczyrzyc. [...] A homily for Sunday, Anno Dni 1691, preached at the church in Szczyrzyc). The author of the homilies delivered at the church in Szczyrzyc was Benedykt Kmita, first subprior and then prior of the monastery in Szczyrzyc under the rule of Abbot Mikołaj Romiszowski ${ }^{16}$. That is noted on the first page: "Fr. Andreas Benedictus Kmita, cysters 1691". The codex consists of 400 folios and was written on paper, in the Polish language. It was probably produced at the monastery in Szczyrzyc. On the blank page preceding the title, Benedykt Kmita wrote an interesting sentence addressed to the potential user: „Co się nie podoba pobożny lektorze, twoja zręczność wrodzona poprawić to może” ("Whatever you do not like, pious reader, you may improve through your own skill"). It is bound in a board covered with black, smooth skin, with surviving marks of two catch plates.

The last manuscript copy, dated to the end of the $17^{\text {th }}$ century (1693), is Tractatus Theologicus de vitiis et peccatis ad mentem D. Thomae Doctoris Angelici sub Dignissimo Proffessore A.R.P. Francisco Kolberg Proffesso

15 J.M. Marszalska, Biblioteka opactwa cystersów w Szczyrzycu do końca XIX stulecia..., item 12, p. 317. The manuscript may have been purchased for the monastery, or brought from the nearby Wiśnicz where the Carmelites had their monastery, founded in 1622 by Stanisław Lubomirski.

16 J. M. Marszalska, Biblioteka opactwa cystersów w Szczyrzycu do końca XIX stulecia... Annex III, item 13, p. 318; J. M. Marszalska, W. Graczyk, Opaci i przeorzy klasztoru oo. Cystersów w Szczyrzycu, p. 146. 
Oliviensi S.O. Cister. An. Dni. 1693. It is a treatise on various topics in dogmatic theology and philosophy, and consists of 422 folios. It was written entirely in Latin by Franciszek Kolberg, a Cistercian of Oliwa. The codex was frequently studied, as can be seen from the heavily effaced marginal glosses, often rendered illegible. Franciszek Kolberg was also the owner of the codex, as is recorded in the ownership note. Like a great majority of $17^{\text {th }}$ century manuscripts, the book does not have any binding ${ }^{17}$.

The most numerous collection of manuscripts preserved in the library dates back to the $18^{\text {th }}$ century - the years $1703-1782$. The collection includes 57 titles, 37 of which have full dating. The greatest share in the collection is that of books in theology, including copies of treatises: De Deo uno et trino D. Thomae(pars I); Praelectiones Theologicae De Inessabilli Incarnationis unae Mysterio; (pars II); Controversiae. De Augustissima et Sanctissima Trinitate (pars III); Disputationes de Iure et Institutia (pars IV); Disputationes. De Altibus Humanis (pars V); Tractatus de Poenitentia ut Sacramentum est (pars VI); Disputationes de Angelis (pars VII); Questiones de Christo cum Hereticis et Insidelibus controversae (pars VIII) ${ }^{18}$; CompendiumDoctrinae Christianae. Ex Gallico et Italico Catechismo quo Congregatio Missionis utitur. Conscripta traduntur Anno Domini 1703. The main body of the manuscript is preceded by a blank page with the text of prayers in Polish: Our Father, Creed, Hail Mary, and Ten Commandments. The treatise was probably copied in Szczyrzyc19.

The next $18^{\text {th }}$ century codex was copied by Jan Rudnicki, a student at the seminary in Krakow, on 7 October 1713. This is attested to by the entry and date appearing on the title page of the manuscript: Compendium Doctrinae Christianae. Conscriptum Anno Dni 1713, die 7 octobris per me Joannem A. Rudnicki iste Alumnum Seminarii Cath. Cracoviensi mpp ${ }^{20}$. Another codex, Catheismus de Septem Sacramentis in genere et in specie. In eius doctrina,

17 J. M. Marszalska, Biblioteka opactwa cystersów w Szczyrzycu do końca XIX stulecia..., Annex III, item 15, p. 318.

18 J. M. Marszalska, Biblioteka opactwa cystersów w Szczyrzycu do końca XIX stulecia..., Annex III, item 15, p. 318. The manuscript's owner was R.P. Morawski, probably a monk at the monastery in Mogiła; he may also have been itscopyist.

19 J. M. Marszalska, Biblioteka opactwa cystersów w Szczyrzycu do końca XIX stulecia..., item 21, p. 321.

20 J. M. Marszalska, Biblioteka opactwa cystersów w Szczyrzycu do końca XIX stulecia..., item 22, p. 321. 
dates back to $1723^{21}$. Four theological treatises were written at the Cistercian scriptorium in Mogiła. In 1746, Theologia Dogmatica. Tractatus secundus: De Angelis et actibus Humanis ${ }^{22}$ was copied, followed by Praelectiones theologicae, finished on 7 December 1748, as can be seen in the note on the title page: Scripta In Collegio Clarotumbano, Studii Provincialis S. O. Cisterciensis, Anno Dni 1748, die 7 decabris ${ }^{23}$. Then, in 1750, a treatise on the sacraments was copied, entitled: Tractatus theologicus de angelis Beatitudine et actibus humanis [...] Praelectiones theologicae de sacramentis, consisting of 400 folios. The scribe added a note which says the manuscript was copied in Lesser Poland - presumably also at the monastery in Mogiła: "Conscriptus Anno 1750, Die 27 decabris. In Minori Polonia"24. In 1773, the College in Mogiła produced a theological treatise on the One God in Trinity: Tractatus Theologicus de Deo Uno et Trino in essentia et Personis ${ }^{25}$.

The second, equally numerous collection of $18^{\text {th }}$ century manuscripts consists of books on philosophy. The most noteworthy of them are: Universa philosophia rationalis, copied by Mikołaj Romiszowski, the abbot of the monastery in Szczyrzyc - as can be seen on the first page of the book "Haec Philosophia scripta est a R. Nicolao Romiszowski, Proff. Ciric. post Abbate Ciricensis qui abbatiali dignitate 43 annis fungens 1727, ex haec vita de cessit"26. The manuscript consists of 521 folios, written in black ink on red paper. It is also worth noting that Mikołaj Romiszkowski organized a course in philosophy for monks in Szczyrzyc in 1690. It was delivered by Father Dominik Engver, a Dominican from the Holy Trinity College in Krakow whom the abbot brought to the monastery with the help of Cistercian monks from Mogiła: "P. Nicolaus Romiszowski incepit

${ }^{21}$ J.M. Marszalska, Biblioteka opactwa cystersów w Szczyrzycu do końca XIX stulecia..., item 28, p. 323.

22 J. M. Marszalska, Biblioteka opactwa cystersów w Szczyrzycu do końca XIX stulecia..., item 35, p. 326.

${ }^{23}$ J. M. Marszalska, Biblioteka opactwa cystersów w Szczyrzycu do końca XIX stulecia..., item 37, p. 326.

${ }^{24}$ J. M. Marszalska, Biblioteka opactwa cystersów w Szczyrzycu do końca XIX stulecia..., item 39, p. 326.

${ }_{25}$ J. M. Marszalska, Biblioteka opactwa cystersów w Szczyrzycu do końca XIX stulecia..., item 50, p. 331. Florian Gotartowski of the Leliwa clan, coming from Prussia. He entered the Cistercian monastery in Pelplin, and was ordained by Wojciech Stanisław Leski, the abbot of Pelplin, in 1793. In the years 1753-1766, he was the abbot of Szczyrzyc, and was then elected the abbot of Pelplin. Cf. J.M. Marszalska, W. Graczyk, Opaci i przeorzy klasztoru oo. Cystersów w Szczyrzycu, p. 163-164.

${ }^{26}$ J. M. Marszalska, Biblioteka opactwa cystersów w Szczyrzycu do końca XIX stulecia..., item 31, p. 31. 
quidem Mogilae, apud PP. Dominicanos Cracoviae Philosophiam perfecit, ad Seminarium vero propter Cistercienses Posnaniae erectum missus ibidem apud PP. Soc. Iesu Philosophiam consumavit, qui Remisovius Abbas factus in suo Conventu propter suos P. Dominicum Engwer ordinum Praedicatorum Anno 1690 Sciricium conduxit, qui biennalem cursum philosophium tyronibus Cisterciensibus cum adiunctis Mogilensibus professis, praelegit [...]"27.

The manuscript was used as a textbook by monks studying in Szczyrzyc. It was copied at the College in Mogiła at the end of 1755 and beginning of 1756: "In Claro Tumbano Collegio sub auspicijs Illustrissimi ac Reverendissimi Domini Constantini Iłowiecki Commissarij per utrumque Poloniam Magnum Ducatum Lithuaniae Abbatis Laudensis Sacri Ordinis Cisterciensis publicae [...] ac disputationis expositus, A.D. 1755, Die 7 decabris" 28 .

The work was copied by Wojciech, a student of philosophy in Mogiła: Hic liber scriptus per Adalbertus Philosophiae studentis Claro Tumbano, finitum A.D. 1756. The book was bound in a parchment manuscript sheet with well-preserved Gothic neumes on four-line staff. The College in Mogiła also produced a manuscript of Philosophiae Rationalis et Experimentalis seu Phisica Generalis. It was copied in 1778 by Romuald Podleski, a Cistercian from Szczyrzyc, professor of philosophy at the College, as can be seen in the note appearing on the first page of the manuscript: "Conscripsit et dictavit Fr. Romualdus Podleski Prof. Ciricien. Sac. Ordin. Cister. [...] actualis in Collegio Mogilensi Philosophiae Proffessor. [XVIII w.], [...] sub Auspicius Illustrissimi ac Reverendissimi Domini Joannis Szołdrski Abbatis Premetensis per utrumque Poloniam, Prussiam, Galliciam et Magnum Ducatum Lithuaniae Commissarii Vicarii nec Visitatoris generalis in Collegio Claro Tumbano Studii Generalis Sacri ac Exempti Ordinis Cisterciensis [...] Anno Dni 1778, Die 7 decabris"29.

An important field of study was canon law. Monasteries endeavoured to own the requisite books on the subject, mostly to be used as textbooks in philosophical and theological studies. The collection of $18^{\text {th }}$ century manuscripts held at the

${ }^{27}$ B. Reydlewicz, Provisio ad mensam Conventualem Sciriciensem Ordinis Cisterciensis, Cracoviensis Diocesis pro fratribus Ab Illustrissimo Revrendissimo Duo Joachimo de Mstow Mstowski Abbate Regulari huius Conventus Anno Domini 1642, Die 24 gloris Assignata ac de Determinata ... Anno 1760, ref. no. 754, p. 289; Jolanta M. Marszalska, W. Graczyk, Opaci i przeorzy klasztoru oo. Cystersów w Szczyrzycu, p. 136.

28 J. M. Marszalska, Biblioteka opactwa cystersów w Szczyrzycu do końca XIX stulecia... Annex III, item 41, p. 327-328.

${ }_{29}$ J. M. Marszalska, Biblioteka opactwa cystersów w Szczyrzycu do końca XIX stulecia..., item 53, p. 322. 
library in Szczyrzyc includes two works on jurisprudence. They are: Iustitia cum Iure suo titulisque suis et reliquis virtutibus Cardinalibus disputationibus Theologicis proposita - a codex consisting of 708 folios, copied in the years $1734-1738$ by one scribe in a very neat, careful hand ${ }^{30}$. The other is Ius canonicumiuxta quinque Libros Decretalium Gregorij IX Pon. Max, copied by Romuald Podleski during the rule of Abbot Onufry Grzymisławski, as can be seen in the note on the first page of the book: Conscripsit publicisque lectionibus vulgavit Fr. Romualdus Podleski Proff. Ciricensis S. Ord. Cisterciensis protunc aqtualis ejusdem juris Proffessor. [18 ${ }^{\text {th }}$ century $]^{31}$.

The monastery also needed books on liturgy. Liturgics was a theological discipline dealing with the content and form of church worship. At the monasteries, special attention was paid to the liturgical celebrations of church holidays and saints related to the spirituality of the order. In the $18^{\text {th }}$ century, a textbook on Cistercian liturgy was added to the library at Szczyrzyc, entitled: Ceremoniale. Privilegia cisterciensia. Confirmatio declarationum Congregationis Consilij super cognitione causarum Regularium. Its manuscript copy including a description of the Cistercian liturgy is dated to 1716. It was copied by three different persons, including a Cistercian monk, Robert Pokulski, whose name is found in the inscription on the title page of the book: Anno Domini 1716, Die 28 Junij, descriptum ex [...] exemplari per Fratrem Robertum Pokulski Proff. Ciric. S.O.C.32

The collection also includes books of homilies dated between 1708-1733:

1. Kazania świąteczne na uroczystości i święta ustanowione przez Kościót Katolicki w wielu miejscach miane. Kazanie na Dzień Św. Apostołów Piotra i Pawla w Zaborowie 1708 (Homilies for feast days and solemnities established by the Catholic Church, delivered at various places. A homily on the Feast of Saints Peter and Paul the Apostles in Zborów 1708);

2. Kazanie na Dzień Niepokalanego Poczęcia Nayśw. Maryi Panny, miane w Kucharach A.D. 1710 (A Homily on the Feast of the Immaculate Conception of Virgin Mary, delivered in Kuchary A.D. 1710);

30 “Ab Anno 1734 in annum 1738. Ad M.D. Gloriam. V. Maris Dei Gratiossisimae et Immaculatae. Semper Honorem. Sanctorum Patronorum Venerationem”. Cf. J. M. Marszalska, Biblioteka opactwa cystersów w Szczyrzycu do końca XIX stulecia... Annex III. item 32, p. 324-325.

31 J. M. Marszalska, Biblioteka opactwa cystersów w Szczyrzycu do końca XIX stulecia..., item 54, p. 333.

32 J. M. Marszalska, Biblioteka opactwa cystersów w Szczyrzycu do końca XIX stulecia..., item 24 , p. 322. 


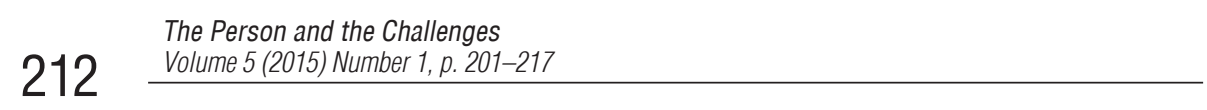

3. Kazanie na dzień Św. Urszuli w Niedziele XXII po Świątkach A.D. 1725 $w$ Czyrzycu przy Primicyjach miane [...] (A Homily on the Feast of St. Ursula on the 22ndSunday after the Pentecost delivered A.D. 1725 in Czyrzyc during the First Mass [...]);

4. Kazanie na Chwalebna Uroczystość Wniebowstapienia Chrystusowego miane w Lędzie, A.D. 1730 (A Homily on the Glorious Day of the Ascension of Christ delivered in Lęda, A.D. 1730);

5. Kazanie na Uroczystość Św. Anny w Kaliszu A.D. 1730 miane u oo. Bernardynów (A Homily on the Feast of St. Anne in Kalisz A.D. 1730 delivered at the Observantine Monastery);

6. Kazanie na Dzień Narodzenia Nayśw. Maryi Panny miane w Biniszowie u oo. Kamedutów A.D. 1733 (A Homily on the Nativity of the Blessed Virgin Mary delivered in Biniszów at the Camaldolese Monastery).

They were copied by the prior of the convent, Benedykt Kmita. The book consists of 440 folios, and was written partially in Polish and partially in Latin. Next to each homily, the date and place of deliveryappears on the $\operatorname{margin}^{33}$. The second collection includes the following homilies: Pro Dominica Resurectionis X. Dominis Anno Dni 1741 - Wschód stońca z Herbowney Fontanny S.O.C. $X$. Infułata Pastoryusza Opata Czyrzyckiego. The manuscript consists of 280 folios, copied by the Cistercian abbot Franciszek Gerard Pastoriusz in Szczyrzyc in 1741, in Polish and Latin. The many underlined passages and numerous marginal glosses show the work was much studied ${ }^{34}$.

Two more manuscripts deserve attention. The first is Connotationes ex actis terrestribus Drohiciensibus Iuxta Libros per annos collocatos per me Gregorium Franciscum Stański Vicesgerensem et Burgrabium Castrensem Mielnicensem in anno 1724 a Die 8 octobris depromptae [...]. The manuscript consists of 698 folios, and includes copies of records kept in the County of Drohiczyn, made by Grzegorz Franciszek Stański, the castellan of Mielnice, in $1724^{35}$. It is not known exactly how it came to be held at the monastery in Szczyrzyc. The other $18^{\text {th }}$ century manuscript is Krótka do nowozaczynajacych nauki szkolne poetów przemowa. [Bajka i przypowiastki rymowane oparte na

${ }_{33}$ J. M. Marszalska, Biblioteka opactwa cystersów w Szczyrzycu do końca XIX stulecia..., item 61, p. 335 .

${ }^{34}$ J. M. Marszalska, Biblioteka opactwa cystersów w Szczyrzycu do końca XIX stulecia... Annex III, item 34, p. 325.

${ }_{35}$ J. M. Marszalska, Biblioteka opactwa cystersów w Szczyrzycu do końca XIX stulecia..., item 30, p. 324. 
mitologii greckiej i rzymskiej] (A Brief Address to Poets Beginning their Studies. [A Tale and Rhymed Parables Based on Greek and Roman Mythology]). It is a manuscript copy of a booklet by Marcin Ośliński, a highly valued neo-Latin poet and panegyrist of Cracow University. An inscription on the title page shows he was the author of the manuscript.

D. M. Martino Ośliński Sacrae Theologiae Doctorae Proffessore Collegiae Maiori Ecclesiarum Praeposito Zielonecensis Curato, Contubernij Hierosolimitani Necnon Scholarum Novodvorscianarum, A.D. $1719^{36}$.

A brief review of $18^{\text {th }}$ century manuscripts held at the library in Szczyrzyc shows that most of them were theological and philosophical works, required for the studies and spiritual formation of monks at the monasteryin Szczyrzyc. Inscriptions on title pages and ownership notes show that many of them were copied by professors and students of the General College in Mogiła, which provided training to the monks of Szczyrzyc, among others. Many of the works were annotated with personal notes and comments. The fact that a great majority of them was not provided with a cover suggests they were intended as textbooks. Exceptions include books provided with the so-called wastepaper binding. Only the codex containing homilies by the Prior of Szczyrzyc, Benedykt Kmita, was bound in a board covered with smooth black skin. Three of the 57 manuscripts dated to the $18^{\text {th }}$ century were authored (or copied) or owned by the Abbots of Szczyrzyc: Marcin Pawlikowski, Mikołaj Romiszowski and Franciszek Gerard Pastoriusz.

The $19^{\text {th }}$ century collection, including 27 titles, is a much smaller selection of manuscripts of a different character. 24 of them were copied by a Cistercian from Szczyrzyc - Romuald Jacek Petrikowicz (1781-1849). He was also the author of many of the prayers, songs and rhyming pieces he copied. They included antiphons, church hymns and Russian songs, psalms, fragments of philosophical treatises, books of anecdotes and various stories about patron saints. Petrikowicz strove to preserve the more valuable and older books, and saved them from falling into complete damage and oblivion. He sometimes added simple, hand-made covers to the manuscripts he copied ${ }^{37}$. All the books he wrote or copied were producedat the monastery in Szczyrzyc or

${ }^{36}$ J. M. Marszalska, Biblioteka opactwa cystersów w Szczyrzycu do końca XIX stulecia..., item 26, p. 322.

${ }^{37}$ Petrikowicz Romuald Jacek (1781-1849), a Cistercian monk at the monastery in Szczyrzyc, coming from Szlachtowa, born to a "Russian rite" family; studied philosophy at the Cistercian monastery in Jędrzejów. From 1817, he held the office of subprior; in 1836, appointed the parish 


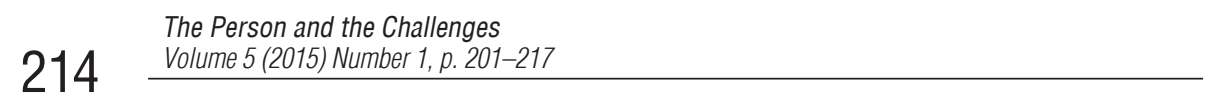

the monastery chapter at St. John Mountain. Most of his works consisted in religious songs, psalms, prayers to Mary the Mother of God, Marian hymns and antiphons. The following works have survived to this day: Antiphona infra Octavas. Dominica infra Octavam. Nativitatis Domini ${ }^{38}$, Officium Commune Apostolorum ad Vigilias ${ }^{39}$, Officium Commune. Beatissimae Virginis Mariae. Ad Vigilias ${ }^{40}$, Vespere $S$. Michaelis Archangeli et S. Angelorum Custodum. [Hymny. Psalmy. (Hymns. Psalms)] $]^{41}$, Laudes Feriarum. Laudes Dominicae per Annum ${ }^{42}$, Officium Parvum Beatae Mariae Virginis ad usum Ordinis Cisterciensis. Praeparatio ante et Gratiarum actio post Missam ${ }^{43}$, Pieśni Kościelne o Świętych Pańskich Kościoła Rzymskokatolickiego i Kościoła Greckokatolickiego (Church Hymns on Roman Catholic and Greek Catholic Saints). The manuscript includes various songs to be used on feast days. The first page features a song on eternity in Russian - rendered into Polish by transliteration ${ }^{44}$. Romuald Petrikowicz's fascination with liturgy and music are reflected in the works he copied or authored himself. He was also interested in other fields of study, such as herbal medicine, botany or history. He compiled an 881-page long work on folk medicine: Rozmaite przepisy na leczenie i sposobienie lekarstw na wszelkie choroby co je powstrzymuja (Various Recipes and the Preparation of Medicines for the Treatment of Diseases). Tomus secundus ${ }^{45}$,

priest of St. John Mountain; a bibliophile and archivist, he was known as a very hardworking and diligent monk.

38 J. M. Marszalska, Biblioteka opactwa cystersów w Szczyrzycu do końca XIX stulecia... Annex III, item 73, p. 339.

39 J. M. Marszalska, Biblioteka opactwa cystersów w Szczyrzycu do końca XIX stulecia..., item 76, p. 340.

${ }^{40}$ J. M. Marszalska, Biblioteka opactwa cystersów w Szczyrzycu do końca XIX stulecia..., item 77, p. 340.

${ }^{41}$ J. M. Marszalska, Biblioteka opactwa cystersów w Szczyrzycu do końca XIX stulecia..., item 81, p. 342.

42 J. M. Marszalska, Biblioteka opactwa cystersów w Szczyrzycu do końca XIX stulecia..., item 84, p. 343.

${ }^{43}$ J. M. Marszalska, Biblioteka opactwa cystersów w Szczyrzycu do końca XIX stulecia..., item 87, p. 344.

${ }_{44}$ J. M. Marszalska, Biblioteka opactwa cystersów w Szczyrzycu do końca XIX stulecia..., item 88, p. 344.

45 J. M. Marszalska, Biblioteka opactwa cystersów w Szczyrzycu do końca XIX stulecia..., item 71, p. 338. 
and Historia SacraVeteris Testamentit ${ }^{46}$, as well as a 394-page long Historia Naturalis Regnum Hungariae ${ }^{47}$.

A work which stands out, from the abundant manuscript legacy of Romuald Jacek Petrikowicz, is a collection of homilies by Franciszek Podleski, a Cistercian of Szczyrzyc, professor of philosophy, theology, law, the Holy Scripture and Church history. Petrikowicz copied that book (633 folios) in 1801 and titled it: Błogostawieństwa Pana Naszego Jezusa Chrystusa uwagami Kaznodzieyskimi y Kwestiami Katechismowemi ozdobione Jasnemi y gruntownemi dowodami tak z Pisma Świętego, jako Oyców Świętych z racji y podobieństw przez Fr. Franciszka Romualda Podleskiego Profesa Sczyrzyckiego Zakonu Cysterskiego ex profesora Filozofii y Teologii Prawa Pisma S. Historyi Kościelney Plebana Nowo Rybskiego przybrane Roku Pańskiego 1801 (The Beatitudes of Our Lord Jesus Christ with A Preacher's Comments and Notes on the Catechism, Adorned with Clear and Thorough Evidence From Both the Holy Scripture and Holy Fathers by Fr. Franciszek Romuald Podleski, an Ordained Monk of the Cistercian Order in Szczyrzyc, ex Professor of Philosophy and Theology, Law, Holy Scripture, Church History, Parish Priest at Nowe Rybie Anno Domini 18014.

The three remaining $18^{\text {th }}$ century manuscripts are the only ones surviving from that period to be fully dated:

1. Hermeneutica secundum. Praelectiones Reverendissimi Domini D. Patris Proffessoris Adalberti Juhn Sacro-Sanctae Theologiae [...] in Budzieioviensi, Eppali [Lycae], 1807 - a work by Wojciech Juhn, professor of theology in Budziejowice, written in 180749;

2. Liber privatae devotionis varijs ex libris excerptus [...] - by Kajetan Bańkowski, a Cistercian of Szczyrzyc, custodian and Sunday preacher, catechist at the Regular School in Szczyrzyc [...] descriptus Frater Caietanus B[ańkowski] Proff. Ciric. 1810

${ }^{46}$ J. M. Marszalska, Biblioteka opactwa cystersów w Szczyrzycu do końca XIX stulecia..., item 75 , p. 340 .

${ }^{47}$ J. M. Marszalska, Biblioteka opactwa cystersów w Szczyrzycu do końca XIX stulecia..., item 82 , p. 342.

${ }^{48}$ J. M. Marszalska, Biblioteka opactwa cystersów w Szczyrzycu do końca XIX stulecia..., item 97, p. 347.

49 J. M. Marszalska, Biblioteka opactwa cystersów w Szczyrzycu do końca XIX stulecia..., item 98, p. 347-348.

${ }^{50}$ J. M. Marszalska, Biblioteka opactwa cystersów w Szczyrzycu do końca XIX stulecia..., item 99, p. 348. 


\section{The Person and the Challenges \\ 216 Volume 5 (2015) Number 1, p. 201-217}

3. Elementhar Mathematik. Erster Theil, die Algebra ... [transl. from German] Johann Fux. Przemyśl, 1827 - a book on mathematics, copied for his own use by Andrzej Sęczakiewicz, first year student of philosophy ${ }^{51}$.

The above collection of manuscripts held at the Cistercian library in Szczyrzyc does not yield itself to a precise summary ${ }^{52}$. The subject-matter and chronological analysis of the manuscripts shows that the surviving specimens are merely "representative" (and that to a limited degree only) of the $17^{\text {th }}$ and $18^{\text {th }}$ century. As has been mentioned earlier, the manuscripts are mostly in the useful form of textbooks, which makes it rather difficult to talk about the interests or influences of particular authors and their works on the intellectual level of the religious community of Szczyrzyc. Its collection of manuscripts does not reflect the bibliophile passions of the monks, with the exception of the small collection of just 27 manuscripts of not much artistic value, dating to the $19^{\text {th }}$ century. Nearly all of them were written by the same person, Romuald Jacek Petrykiewicz, and are more a reflection of his interests and talents rather than the demand for such type of literature at the monastery.

The collection of manuscripts lacks the oldest, medieval works (and copies) of the theological writers of the age, who were numerously represented in the $15^{\text {th }}$ century collection of incunabula by printed editions of Albertus Magnus, Angelus de Clavasio, Saint Bernard of Clarivaux, Saint Vincent of Ferrara, and a copy of the famous work by Thomas a Kempis De Imitatione Christi. The explanation for the lack of many writers and works on the library shelves may be twofold: either the oldest part of the collection was destroyed, which was not recorded in the monastery's chronicles, or the order never purchased them at all. Throughout the 780 years of its history, the monastery (founded in 1234) has never been dissolved, and its library collection has never been removed elsewhere. Perhaps the medieval monks of Szczyrzyc were more concerned with enlarging (through exchange and acquisition) and defending their possessions against their neighbours than with studying and copying works by the outstanding theologians and philosophers of their time.

The collection of later manuscripts $\left(17^{\text {th }}\right.$ and $18^{\text {th }}$ century) in the library of the monastery in Szczyrzyc is mostly a functional one; it was used by the monks to

${ }^{51}$ J. M. Marszalska, Biblioteka opactwa cystersów w Szczyrzycu do końca XIX stulecia..., item 100 , p. 348 .

${ }^{52}$ A preliminary inventory made at the library in Szczyrzyc showed 77 incunabula and approximately 3.5 thousand old prints dated to the $16^{\text {th }}, 17^{\text {th }}$ and $18^{\text {th }}$ century. 
study and broaden their philosophical, theological, legal and liturgical knowledge. Several codices contain the texts of homilies delivered at various churches on feast days and solemnities and written down by the monks of Szczyrzyc. The scanty number of the oldest, medieval codices is apparent, with only four surviving to this day, all dated to the $15^{\text {th }}$ century. There are no $16^{\text {th }}$ century books in the collection. The $17^{\text {th }}$ and $18^{\text {th }}$ centuries are definitely in the lead; as has been mentioned, they are mostly represented by textbooks. This is particularly visible in the period of the increased academic activity of the Studium Generale in Mogiła, which provided training and education to Cistercian monks for the entire province. It is worth noting that in the surviving collection of printed books, beginning with incunabula, through the $16^{\text {th }}, 17^{\text {th }}$ and $18^{\text {th }}$ centuries, many books have covers made fromfolios takenout from Medieval codices once held at the monastery, mostly from damaged pages from liturgical codices, including antiphonaries and graduals. They represent a valuable resource for studies on the liturgy (but not only) of Cistercian monks in Szczyrzyc, including the culture of the written word and the artistry and craftsmanship of Medieval scribes and illuminators related to the religious circles of Lesser Poland.

\section{Bibliography}

Inventarium Cijrzickiego Kościoła ... conscriptus R.P. Antonius Stawski...1728-1740

Marszalska J. M., Biblioteka opactwa cystersów w Szczyrzycu do końca XIX stulecia. Dziedzictwo wieków, Tarnów 2007.

Marszalska J.M., Najważniejsze źródta rękopiśmienne do dziejów klasztoru oo. Cystersów w Szczyrzycu, "Nasza Przeszłość" 104 (2005), p. 37-70.

Marszalska J. M., Opaci komendataryjni wobec książki. Przyczynek do dziejów opactwa Cystersów w Szczyrzycu, w: Klasztor w państwie średniowiecznym i nowożytnym, ed. M. Derwich, A. Pobóg- Lenartowicz, Wrocław-Opole-Warszawa 2005, p. 351-363.

Marszalska J.M., Graczyk W., Opaci i przeorzy klasztoru oo. Cystersów w Szczyrzycu od XIII do XX wieku, Kraków 2006.

Potkowski E., Książka rękopiśmienna w kulturze Polski, Warszawa 1984.

Reydlewicz B., Provisio ad mensam Conventualem Sciriciensem Ordinis Cisterciensis, Cracoviensis Diocesis pro fratribus Ab Illustrissimo Revrendissimo Duo Joachimo de Mstow Mstowski Abbate Regulari huius Conventus Anno Domini 1642. 
